\title{
抗うつ薬により誘導される 海馬歯状回シナプス形態変化
}

要約 : 抗うつ薬としてセロトニン再取込み阻害薬 （SSRI）が多く使われているが，治療効果は十分とは 言えない，治療効果を改善するためには，うつ病の病 態と抗うつ薬の作用機序について理解を深める必要が ある. 抗うつ薬の標的脳部位の 1 つとして, 海馬歯状 回が注目されている. 海馬歯状回では, 抗うつ薬によ り脳由来神経栄養因子 (BDNF) の発現が増加し, シ ナプスの可塑的な変化を起こして神経回路の機能異常 を改善する．また，抗うつ薬は神経新生を促進する。 最近では, 抗うつ薬は成熟顆粒細胞に作用して, 興奮 性を高めると同時に, 成熟マーカー遺伝子の発現を抑 制することが知られている。 そこで, SSRIであるフル オキセチンの慢性投与により神経伝達が元進している 海馬歯状回の貫通線維 - 顆粒細胞シナプスの形態を, 電顕レベルの解像度で詳細に検討した。具体的には, 集束イオンビーム／走査型電子顕微鏡（FIB/SEM）を 用いて連続電顕画像を取得してシナプス構造を $3 \mathrm{D}$ 電 顕画像として再構築し, 形態解析を行った。 その結果, フルオキセチン慢性投与により極端に大きなスパイン (顆粒細胞樹状突起) が出現し, 大きなスパインのシナ プス後肥厚（PSD）も増大していた．また，大きなス パインには大きな神経終末ボタン (貫通線維) が接触 しており, 大きな神経終末ボタンには大きなミトコン ドリアと多くのシナプス小胞が含まれていた．大きな 貫通線維一顆粒細胞シナプスはシナプス伝達を促進す るシナプス前およびシナプス後の構造を伴っており， 神経伝達を促進する可塑的変化を反映すると考えられ た.このシナプス形態変化には, 抗うつ薬により発現 が調節される遺伝子, 特にBDNFなどの液性因子の関 与が大きいと考えられるが，現時点では責任分子は明 らかではない。また，樹状突起のスパイン，貫通線維
の神経終末ボタンにおいて, 全てのスパインや神経終 末ボタンが大きくなったわけではなく, 抗うつ薬が限 局したシナプスにおいてシナプス形態と可塑性を調節 する分子メカニズムの解明が今後の課題である.

\section{1.はじめに}

うつ病の治療にセロトニン再取込み阻害薬（selective serotonin reuptake inhibitor：SSRI）をはじめとする抗 うつ薬が用いられているが，その効果は十分とは言え ない.うつ病の病態には神経新生の抑制, シナプス数 の減少, シナプス伝達効率の低下などが関係し, 神経 回路の機能異常を来していると考えられている $(1,2)$. 抗うつ薬の慢性投与は, 神経可塑性を調節することに より, 神経回路機能を改善して抗うつ薬作用を発揮す ると考えられている $(1,2)$. 特に, 海馬歯状回では, SSRIにより神経新生が促進することに加え $(3,4)$, 既 存の成熟顆粒細胞において calbindin や tryptophan-2.3dioxygenase といった成熟顆粒細胞マーカー遺伝子の 発現が低下して, 成熟顆粒細胞の興奮性が充進するこ とが報告されている $(5)$ ．このことは，海馬歯状回は 抗うつ薬の標的脳部位であることを示唆している.

\section{2. フルオキセチンによるシナプス伝達の増強}

海馬歯状回は嗅内皮質から貫通線維（グルタミン酸 作動性）の入力を受け, 貫通線維は歯状回の顆粒細胞 と貫通線維一顆粒細胞シナプスを形成する。我々は, フルオキセチン慢性投与が貫通線維 一顆粒細胞シナプ ス伝達に及ぼす影響を明らかにするために, 膜電位感 受性色素を用いて機能解析を行った（図 1)。マウス脳 より海馬スライスを作製し, 歯状回への入力線維であ る内側貫通線維を電気刺激すると，貫通線維一顆粒細

キーワード：抗うつ薬，海馬歯状回，貫通線維－顆粒細胞シナプス，3D 電顕画像，神経可塑性

久留米大学 医学部 薬理学講座（ $=830-0011$ 福岡県久留米市旭町 67)

E-mail: nishia@med.kurume-u.ac.jp 原稿受領日 : 2016 年 6 月 21 日，依頼原稿

Title: Antidepressant-induced changes in synaptic morphology in the mouse dentate gyrus

Author: Yosuke Kitahara, Akinori Nishi 


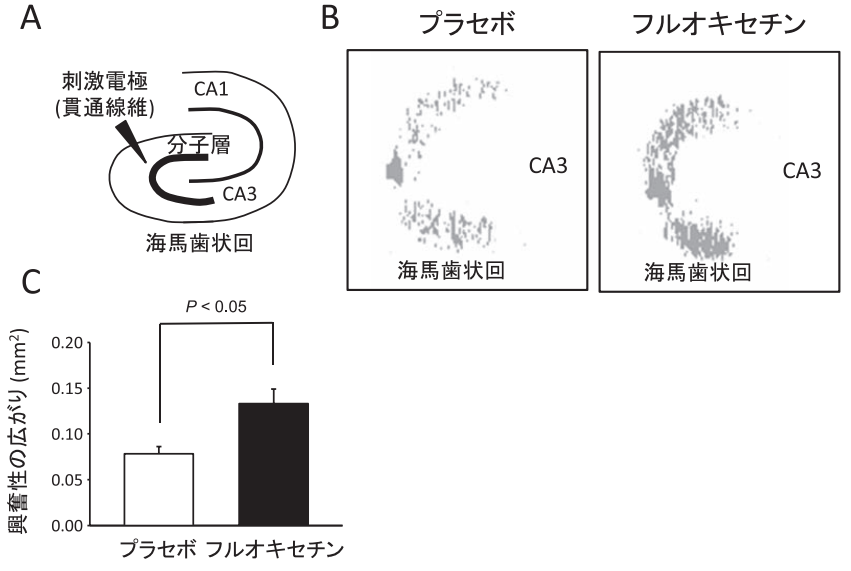

図 1 マウス海馬歯状回の貫通線維一顆粒細胞シナプス伝達に対す るフルオキセチン慢性投与の影響

（A）内側貫通線維を電気刺激し，シナプス伝達により興奮する顆粒細胞 樹状突起の領域（分子層）を膜電位感受性色素を用いて検出した。（B， C）閾值以上の膜電位上昇（興奮）を示す領域は，フルオキセチン慢性 投与群（15 mg/kg を2 週間, 徐放性ペレットとして皮下投与）で増大 していた. (文献6より転載)

胞シナプス伝達により膜電位が上昇する分子層領域を 検出することができた。この分子層領域は顆粒細胞樹 状突起の興奮領域を意味する。フフルオキチン慢性投 与により分子層の興奮領域が拡大したことより，フル オキセチン慢性投与はグルタミン酸作動性の貫通線 維一顆粒細胞シナプス伝達を増強したと考えられた(6). この結果は, 抗うつ薬により顆粒細胞の興奮性が元進
し(5)，貫通線維 - 顆粒細胞シナプスの可塑性が変化 するという報告と一致する $(5,7,8)$. シナプス可塑性 の変化は実験条件により異なるが，本研究と同じよう に抑制性 $\mathrm{GABA}_{\mathrm{A}}$ 受容体機能を保った条件では長期増 強 (long-term potentiation : LTP) の充進が報告されて おり (8)，フルオキセチン慢性投与による貫通線維一 顆粒細胞シナプス伝達の増強は LTP 充進と一致する 可塑的変化と考えられる.

\section{3. フルオキセチンによる樹状突起スパインの 形態変化}

興奮性シナプスでは, グルタミン酸刺激に対する興 奮性シナプス後電流がスパインの体積に比例して増 加することが報告されている(9). さらに, 可塑的変 化として LTPを示す場合には, スパインの体積や密度 が増加していることが知られている(10)。フルオキ セチン慢性投与により貫通線維一顆粒細胞シナプス伝 達が充進することを明らかにしたが，このシナプス 機能変化がシナプスの形態や密度の変化を伴うかどう かは知られていない。 そこで，集束イオンビーム／走 査型電子顕微鏡 (focused ion beam/scanning electron microscopy：FIB/SEM）を用いて連続電顕画像を取 得してシナプス構造を 3 次元再構築し, 形態解析を 行った(6). 図 2Aに示すように, マウス歯状回顆粒細

A

B
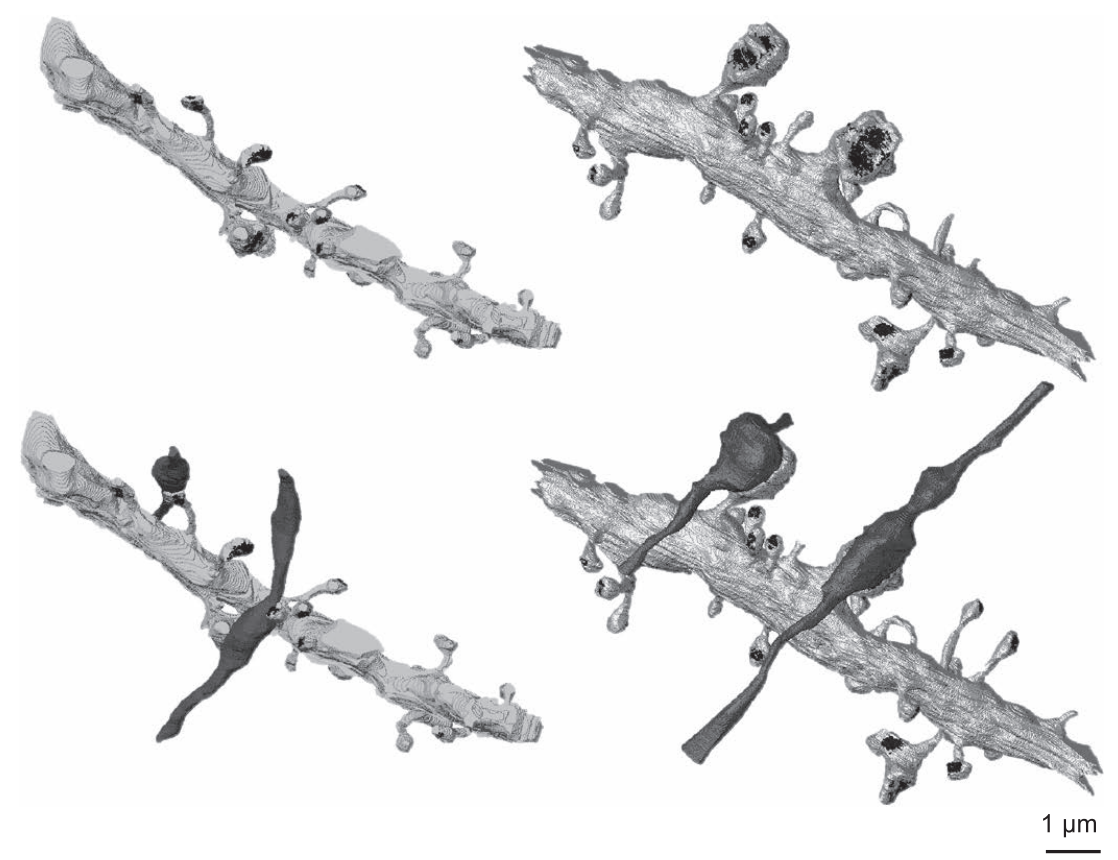

図 2 フルオキセチン慢性投与による貫通線維一顆粒細胞シナプスの形態変化

マウス海馬歯状回分子層において FIB/SEM を用いて得られた連続電顕画像を $3 D$ 再構築し，顆粒細胞の樹状突起亡スパイン，貫通線維の神経 終末ボタンを描出した。（A）フルオキセチン慢性投与群（15 mg/kg を2 週間，徐放性ペレットとして皮下投与）では，極端に大きしスパイン を認めた. 大きいスパインではPSD（黒）も増大していた（B）大きいスパインには大きな神経終末ボタンが接触していた（文献6より転載） 
胞の樹状突起とスパインの $3 \mathrm{D}$ 画像を電顕の解像度で 描出することができた。フルオキセチンを慢性投与し たマウスでは，極端に大きな体積（プラセボ群スパイ ン体積の平均值 +2 S.D. 以上）を持つスパインの出現 を認めた. フルオキセチン慢性投与により, スパイン 体積の平均值も増加したが， スパイン密度の有意な変 化は認めなかった。

スパイン頭部には AMPA 受容体や NMDA 受容体な どのタンパク質の複合体であるシナプス後肥厚 (PSD) が局在し, 電子顕微鏡において電子密度の高い 構造として観察される. PSDの厚さがシナプス前膜 に比べて極端に厚いものは非対称性シナプスと呼ばれ， 興奮性シナプスの特徵である。興奮性シナプスの PSD 体積を解析すると，これまでの報告 (11) と同様 に, PSD 体積はスパイン体積に比例して増加していた。 つまり，フルオキセチン慢性投与によって誘導された 大きいスパインには, 大きいPSDが局在していた。し かし，フルオキセチン慢性投与は，スパイン体積と PSD 体積の相関関係には影響しなかった. シナプス の伝達効率が増加するにつれて PSD の大きさが増加 することが報告されており(12)，フルオキセチン慢性 投与によって誘導された大きいスパインにおける PSD の増大は, シナプス伝達の充進に関与することが 示唆された。

抗うつ薬慢性投与は, 海馬歯状回において神経新生 を誘導する $(3,4)$. 神経新生によりターンオーバー する神経細胞はラットで顆粒細胞全体の $6 \%$ 程度で あると報告されており (13), 抗うつ薬投与によって神 経新生が促進されたとしても $90 \%$ 以上の顆粒細胞は 成熟顆粒細胞と考えられる。解析を行ったほとんどの 樹状突起で大きいスパインの出現を認めたため, フル オキセチンは既存の成熟顆粒細胞に作用してスパイン の形態変化を誘導したと考えられる。海馬における 神経新生を抑制した状態でも, 抗うつ薬は慢性ストレ スによる顆粒細胞樹状突起の萎縮を改善すること, シ ナプス再構築に関わる neural cell adhesion molecule 1 （NCAM1）の発現を増加させること, 成熟顆粒細胞の マーカーである calbindin の発現を抑制することが報 告されている $(14,15)$.これらの報告は, 抗うつ薬に よる成熟顆粒細胞のスパイン形態変化には, 神経新生 に依存しない抗うつ薬作用が関与することを示唆して いる.

抗うつ薬が海馬のスパイン形態や密度に及ぼす影響 について、これまでに幾つかの報告がある.フルオキ セチン慢性投与により, 歯状回や CA1, CA3 のスパイ ン密度が増加することが報告されている(16-18)。ま
た，フルオキセチン慢性投与により，歯状回分子層に おいて, マウスの月齢依存的 (10月齢で増加するが, 4 月齢では増加しない）にスパイン密度に加えてスパイ ンサイズが増加することが報告されている(17)，抗う つ薬によりスパイン密度が増加する報告は散見される が，スパイン形態変化に関するするもの $(14,17,19)$ は限定されている，その理由として，これまでのスパ イン形態解析は光学顕微鏡を用いて実施されており, スパイン形態の変化を正確に捉えることができなかっ た可能性がある. 今回, 我々はスパイン構造を $3 \mathrm{D}$ 電 顕画像として解析したことで，スパインの形態変化を 正確かつ詳細に捉えることができたと考えている.

\section{4. フルオキセチン慢性投与による神経終末ボ タンの形態変化}

FIB/SEM を用いた 3D 電顕画像解析では, スパイン に対応した神経終末ボタン（presynaptic bouton）の $3 \mathrm{D}$ 電顕画像を描出することができる。この特性を生 かして, 貫通線維の神経終末ボタンの形態を解析した ところ(6)，フルオキセチン群で見られた大きなスパ インには，大きな神経終末ボタンの接触が観察された (図 2B).ささらに, 大きな神経終末ボタン内には, 大き なミトコンドリアが存在し, シナプス小胞量の増加が 認められた (図 3)。神経終末ボタン内のミトコンドリ ア体積とシナプス小胞量 (総体積) を定量解析した結 果, 神経終末ボタンの大きさに比例してミトコンドリ アの大きさとシナプス小胞の量が増加することを見出 した. しかし，これらの相関関係は，フルオキセチン の慢性投与によって影響されなかった。なお，個々の シナプス小胞のサイズには変化はなく, シナプス小胞 量の増加はシナプス小胞数の増加として捉えることが できた。

神経終末ボタンの大きさには多様性があり, 小さい ものから大きいものまで幅広い(20)。これまでに, 神 経終末ボタンが大きくなるにつれてシナプスの伝達効 率が増強すること (12), 神経終末ボタンの体積に比例 してミトコンドリアとシナプス小胞の体積が増加する こと(21-23), 神経終末ボタンのミトコンドリアとシ ナプス小胞量の増加はシナプスの伝達効率を増加させ ること $(24,25)$ が報告されている. したがって，フル オキセチン慢性投与により誘導された大きい神経終末 ボタンは, ミトコンドリアとシナプス小胞量の増加を 伴っており，シナプス伝達を増強するシナプス前細胞 の構造的因子として捉えることができる. 

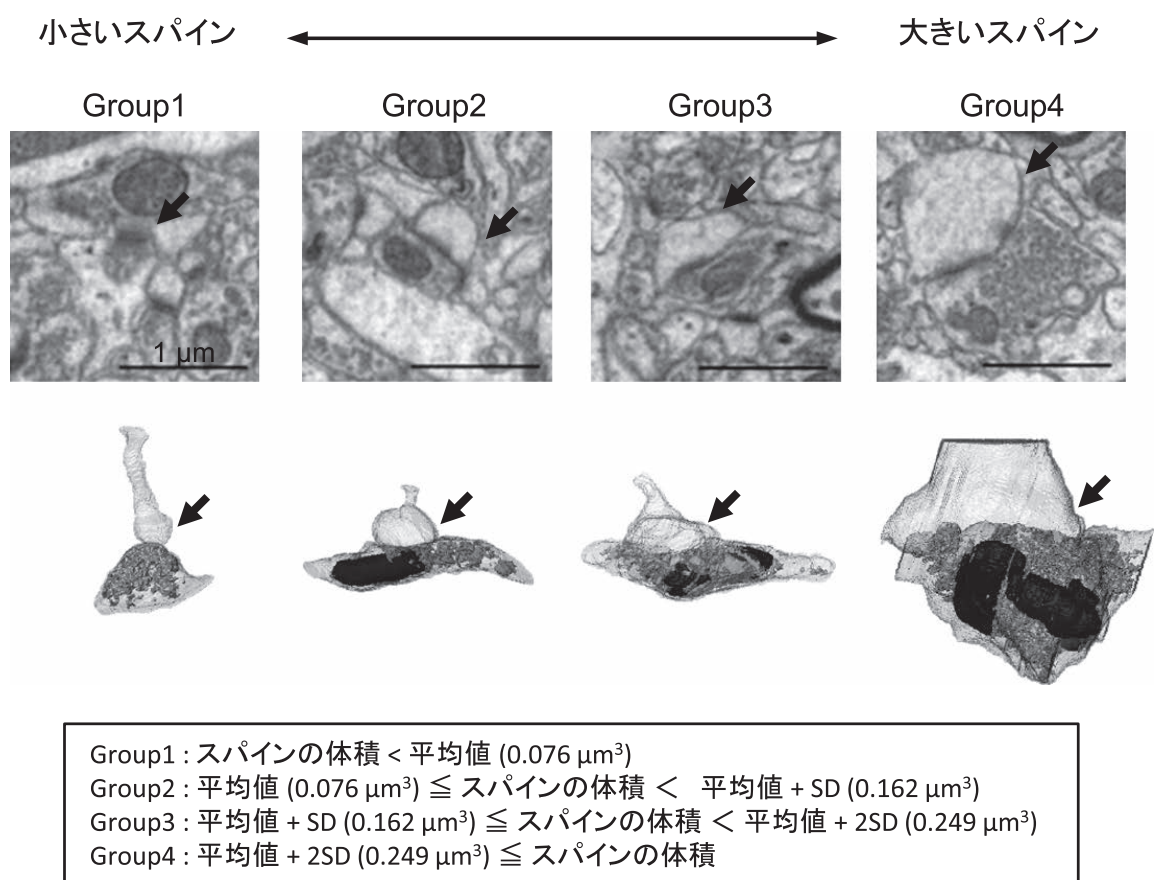

\section{図 3 スパイン体積と接触する神経終末ボタン体積の相関性}

フルオキセチン慢性投与群の貫通線維一顆粒細胞シナプス画像を示す. プラセボ群のスパイン体積の平均值と S.D. を使って，スパインを 4 つ のサイズに区分した．スパイン（矢印）のサイズが大きくなるにつれて，接触する神経終末ボタンの体積が増大した．また，大きな神経終末ボ タンには, 大きなミトコンドリアと多くのシナプス小胞が含まれていた. しかし，フルオキセチン慢性投与はこれらの相関性には影響しなかっ た. (文献 6 より転載)

\section{5. 貫通線維一顆粒細胞シナプス形態変化を誘 導する抗うつ薬関連分子}

シナプスの形態変化を誘導する多くの分子メカニ ズムが同定されているが(26), フルオキセチン慢性 投与が貫通線維 - 顆粒細胞シナプスの形態変化を誘導 する分子メカニズムは現時点では明らかではない. 抗うつ薬は, 海馬歯状回に扮いて脳由来神経栄養因 子（BDNF）の発現を促進することが知られている $(27,28)$ 。また, BDNF シグナルは, シナプスの可塑 的変化を伴ったスパインサイズの増大に重要な役割を 担っている $(29,30)$. さらに, フルオキセチン慢性投 与は BDNF の下流シグナルである mTOR の作用を増 強し, PSD の足場タンパク質である PSD-95 の発現を 増加させることが報告されている(31)。貫通線維－顆 粒細胞シナプスの可塑的変化に加えて, 形態的変化に も BDNFが関与することが示唆される.

また, 抗うつ薬慢性投与は成熟顆粒細胞の成熟マー カー遺伝子の発現を低下させ, 成熟顆粒細胞の興奮性 を促進する (5). 発現が低下する成熟マーカー遺伝子 として, calbindin, tryptophan-2.3-dioxygenase, IL-1 $\beta$ receptor な゙があり, このような分子の関与も検討す る必要がある。なお, 成熟顆粒細胞の機能変化は $5-\mathrm{HT}_{4}$ 受容体を介すること $(5,15), 5-\mathrm{HT}_{2 \mathrm{~A}}$ 受容体は kalirin-7 を介してスパイン形成を調節すること(32) が 報告されており，抗うつ薬によるセロトニンシグナル の促進がスパインサイズ増大の誘因と考えられる.

大きなスパインには大きな神経終末ボタンが結合し てシナプスを形成しているが，この関係性はフルオキ セチン慢性投与により出現した大きなシナプスでも維 持されている．神経終末ボタンの機能や形態は，シナ プスの活動性，接着分子や液性因子（BDNF，纎維芽 細胞増殖因子 (FGF)，Wnt など）によって調節されて いる(33-37)．抗うつ薬は BDNF，FGF，Wntなどの 液性因子を活性化することが知られている(38). 特に, BDNF シグナルの活性化は mTOR を介して synapsin I の発現を増加させる作用もあり (31), 大きい神経終末 ボタンの形成に関与している可能性が考えられる.

\section{6. おわりに}

大きいスパインは, 同じ樹状突起のスパインに広範 に認められるのではなく, 限られたスパインでのみ誘 導されている. また, 貫通線維の神経終末ボタンは大 きいスパインと接触している場合は大きいが, 同じ貫 通線維の全ての神経終末ボタンが大きいわけではない (図 4)。スパイン側と神経終末ボタン側の調節因子が 協調して大きなシナプスを形成し(34), シナプス伝達 を促進するために必要なシナプス小胞，ミトコンドリ 


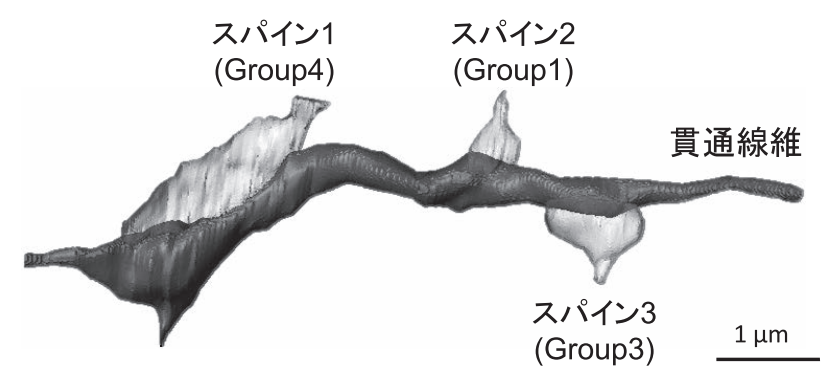

図 4 貫通線維とシナプスを形成する複数のスパイン

1 本の貫通線維は複数の神経終末ボ夕ン構造を持ち, スパインと接触し て貫通線維一顆粒細胞シナプスを形成する。 スパイン1（サイズ： Group4）と接触する神経終末ボタンは大きなシナプスを形成している が，この貫通線維の全てのシナプスが大きいわけではない. シナプスサ イズの変動にはシナプス局所の因子が影響すると考えられる.

ア, PSD 等の増大を伴っている. 大きな貫通線維一顆 粒細胞シナプスでは, 局所的にBDNFなどの液性因子 の活性化と神経伝達の立進が起こっていると考えられ る(29). 今後, 抗うつ薬による顆粒細胞での遺伝子発 現調節と限局したシナプスでの形態および可塑的変化 の関連性について解析を進める必要性がある.

著者の利益相反 : 開示すべき利益相反はない.

\section{文献}

1) Castrén E. Nat Rev Neurosci. 2005;6:241-246.

2) Castrén E, et al. Trends Neurosci. 2013;36:259-267.
3) Malberg JE, et al. J Neurosci. 2000;20:9104-9110.

4) Santarelli L, et al. Science. 2003;301:805-809.

5) Kobayashi K, et al. Proc Natl Acad Sci U S A. 2010;107:84348439.

6) Kitahara Y, et al. PLoS One. 2016;11:e0147307.

7) Airan RD, et al. Science. 2007;317:819-823.

8) Wang JW, et al. J Neurosci. 2008;28:1374-1384.

9) Matsuzaki M, et al. Nat Neurosci. 2001;4:1086-1092.

10) Segal M. Nat Rev Neurosci. 2005;6:277-284.

11) Arellano JI, et al. Front Neurosci. 2007;1:131-143.

12) Meyer $D$, et al. Neuron. 2014;82:430-443.

13) Cameron HA, et al. J Comp Neurol. 2001;435:406-417.

14) Bessa JM, et al. Mol Psychiatry. 2009;14:764-773, 739.

15) Imoto $Y$, et al. Mol Brain. 2015;8:29.

16) Huang GJ, et al. PLoS One. 2012;7:e35901.

17) McAvoy K, et al. Hippocampus. 2015;25:1429-1446.

18) Hajszan T, et al. Eur J Neurosci. 2005;21:1299-1303.

19) Rubio FJ, et al. Front Cell Neurosci. 2013;7:66.

20) Bourne JN, et al. J Comp Neurol. 2013;521:3898-3912.

21) Rollenhagen A, et al. Brain Struct Funct. 2014;220:3185-3209.

22) Murthy VN, et al. Neuron. 2001;32:673-682.

23) Knott GW, et al. Nat Neurosci. 2006;9:1117-1124.

24) Sun T, et al. Cell Rep. 2013;4:413-419.

25) Greenwood JS, et al. Ann Neurol. 2009;66:644-653.

26) Murakoshi H, et al. Trends Neurosci. 2012;35:135-143.

27) Baj G, et al. Neuropsychopharmacology. 2012;37:1600-1611.

28) Duman RS, et al. Biol Psychiatry. 2006;59:1116-1127.

29) Tanaka J, et al. Science. 2008;319:1683-1687.

30) Yoshii A, et al. Dev Neurobiol. 2010;70:304-322.

31) Liu XL, et al. Sci Rep. 2015;5:16024.

32) Jones KA, et al. Proc Natl Acad Sci U S A. 2009;106:1957519580.

33) Dalva MB, et al. Nat Rev Neurosci. 2007;8:206-220.

34) Johnson-Venkatesh EM, et al. Eur J Neurosci. 2010;32:181-190.

35) Luikart BW, et al. J Neurosci. 2005;25:3774-3786.

36) Gogolla N, et al. Neuron. 2009;62:510-525.

37) Terauchi A, et al. Nature. 2010;465:783-787.

38) Pilar-Cuéllar F, et al. Neural Plast. 2013;2013:537265. 